\title{
OBITUÁRIO PROFESSOR ARYON RODRIGUES
}

\begin{abstract}
A Revista Delta lamenta profundamente o falecimento do Professor Doutor Aryon Dall Igna Rodrigues, dia 26/04/2014, aos 88 anos, em Brasília. Eminente pesquisador na área da linguística indígena, sua importância estende-se a toda a ciência linguística no Brasil. $\mathrm{O}$ primeiro brasileiro Doutor em Linguística, foi fundador do Laboratório de Línguas Indígenas do Instituto de Letras da Universidade de Brasília, tendo chegado ao Distrito Federal, em 1962, com um grupo de estudiosos, a convite de Darcy Ribeiro, para dar início à UnB, de lá se retirou em apoio a colegas demitidos e para onde retornou depois de abrilhantar outros importantes departamentos no Museu Nacional e na Universidade de Campinas. Aryon Rodrigues trabalhou até os 87 anos, deixou três filhos e importante herança, resultado de anos de trabalho: 17 obras, entre 1951 e 1992, um acervo com mais de 20 mil livros e revistas sobre línguas e culturas indígenas e muitos seguidores. Professor emérito e doutor honoris causa, a linguística sofre uma enorme perda.
\end{abstract}

Leila Barbara e demais membros da DELTA e da comunidade linguística.

O Prof. Aryon Rodrigues deixou um legado inestimável para a linguística e notadamente para o estudo das línguas indígenas brasileiras. Com seu trabalho, contribuiu não só para o avanço da ciência, pelo tratamento original dos fenômenos analisados, pela documentação cuidadosa dessas línguas, pela formação de inúmeros linguistas, como também para a afirmação dos povos indígenas, os quais habitam o ter- 
ritório brasileiro desde sempre e nele ergueram o patrimônio precioso de sua cultura e das numerosas línguas que se transmitiram através das gerações. Ao Professor Aryon Rodrigues nosso respeito e agradecimento. Aos/às alunos/as e ex-alunos/as, parceiros/as de pesquisas, colaboradores/as nossa solidariedade.

Heloisa Salles (Universidade de Brasília), Paulo Salles e família.

Campinas, 1989. Eu estava no Brasil para estudar a fonologia do português brasileiro. Aryon e Daniele tinham me convidado para morar na sua casa, no campus da UNICAMP, onde coabitava com o que era provavelmente a mais completa biblioteca das línguas nativas da América do Sul. Em vez de aprender o português do Brasil, li as dissertações, as teses e os livros sobre os índios e suas línguas, uma oportunidade imprevista que mudou profundamente minha vida. Por esse fato, ficarei para sempre em dívida com Aryon e Daniele.

Com meus sinceros agradecimentos a um grande linguista.

Leo Wetzels (LET. VU)

A linguística brasileira perde, nestes dias, um dos expoentes da linguística no país, deixando saudades em toda uma geração de linguístas. O professor Aryon, que foi uma autoridade nas línguas indígenas brasileiras, não só formou uma geração inteira de indigenistas, mas teve um papel ímpar na linguística brasileira, ajudando a formar alguns dos principais centros de pós-graduação no país (Brasília, Rio, Campinas) e trazendo Ph.Ds do exterior. Pessoalmente, tive a honra de tê-lo como membro da banca no meu primeiro concurso de titular na PUC de São Paulo, após o qual tive o prazer de ser sua colega na UNICAMP, antes dele se mudar para a Universidade de Brasília.

Mary A. Kato (UNICAMP) 
Conheci o professor Aryon quando eu era um recém-graduado, nos Institutos Brasileiros de Linguística de 1969 e 1970. Mais tarde fomos colegas na UNICAMP, e também o encontrei em comissões da CAPES e em congressos e reuniões durante muitos anos. Uma coisa que sempre me impressionou no Aryon era sua atitude pé-na-terra, seu compromisso com fatos da língua (e das línguas que ele estudava); sempre o achei uma criatura realista em termos da disciplina, sem aqueles deslumbramentos teóricos que às vezes põem boas mentes a perder. Além disso, era uma verdadeira enciclopédia, e não apenas no que diz respeito a línguas indígenas. Meu relacionamento com ele foi sempre agradável, embora ele tivesse o hábito de, depois de oito ou dez anos sem me ver, chegar e ir dizendo (com seu sotaque inconfundível) "Bom dia, Perini", como se tivesse me encontrado na véspera. Com seu falecimento desaparece um modelo de profissional da nossa área, e a linguística brasileira fica muito mais pobre.

Mário A. Perini

O professor Aryon Rodrigues morreu. Todos sabem o quanto eu gostava dele, e vou sempre gostar. Uma despedida muito triste para mim. Mas como um pai, ficará em mim para sempre. Muitos de meus trabalhos e interesses são inspirados por ele: nasalização, hierarquia de pessoa, estudo sobre relacional e contiguidade do objeto-verbo. Não compartilhamos a mesma teoria, mas foi ele mesmo que me apresentou ao gerativismo e me disse para ir em frente quando era meu orientador de iniciação científica na UNICAMP. O Aryon deu direcionamento para minha vida com grande apoio. Tem trabalhos do Aryon que eu li tantas vezes na minha vida e continuo lendo, e me impressionando, e continuo usando como orientação eterna. O mundo perde sem ele, mas tenho certeza de que ele permanecerá em mim e em muita gente. Meu pai Aryon, perco um pai mais uma vez. Obrigada Aryon.

Filomena Sândalo (UNICAMP) 